BOLETIN LATINOAMERICANO Y DEL CARIBE DE PLANTAS MEDICINALES Y AROMÁTICAS

19 (6): 580 - 590 (2020)

(C) / ISSN 07177917 / www.blacpma.ms-editions.cl

\title{
Artículo Original | Original Article \\ Phenolic compounds of Tagetes lucida Cav. with antibacterial effect due to membrane damage
}

[Compuestos fenólicos de Tagetes lucida Cav. con efecto antibacteriano por daños a la membrana]

\author{
Perla Y. Villa-Silva ${ }^{1}$, Anna Iliná1, Juan A. Ascacio-Valdés ${ }^{1}$, Sandra C. Esparza-González², \\ Luis Enrique Cobos-Puc ${ }^{1}$, Raúl Rodríguez-Herrera ${ }^{1}$ \& Sonia Y. Silva-Belmares ${ }^{1}$ \\ ${ }^{1}$ Faculty of Chemistry and ${ }^{2}$ Faculty of Odontology \\ Autonomous University of Coahuila, Saltillo, Coahuila, México \\ Contactos | Contacts: Sonia Y.SILVA-BELMARES - E-mail address: yesenia_silva@uadec.edu.mx
}

\begin{abstract}
Tagetes lucida Cav. (Asteraceae=Compositae) is used for treating stomach infections. The study focused on evaluating the composition and antimicrobial effect of an extract of T. lucida Cav. The plant extracted with ethanol at $10 \%$ w/v, and the extract composition analyzed by Rp-HPLC-MS. The antibacterial effect was evaluated against Staphylococcus aureus, Escherichia coli, Pseudomonas aeruginosa, and Salmonella choleraesuis using disk diffusion, microdilution and bioautography methods. The sytox and comet assays were used to evaluate the mechanism of action. In this way, nine phenolic compounds were detected in the extract of $T$. lucida. The extract exhibited activity only on $S$. aureus (MIC of $4.000 \mathrm{mg} / \mathrm{ml}$ ). The bioautography revealed that the phenolic compounds could act synergistically. The sytox and comet tests showed an antibacterial action of the extract on the bacterial membrane and DNA of this bacterial strain.
\end{abstract}

Keywords: Tagetes lucida Cav.; Chemical composition; Antibacterial effect; Action target

Resumen: Tagetes lucida Cav. (Asteraceae = Compositae) se usa para tratar infecciones estomacales. El estudio se centró en evaluar la composición y el efecto antimicrobiano de un extracto de T. lucida Cav. La planta se extrajo con etanol al 10\% p/v, y la composición del extracto se analizó por Rp-HPLC-MS. El efecto antibacteriano se evaluó contra Staphylococcus aureus, Escherichia coli, Pseudomonas aeruginosa y Salmonella choleraesuis utilizando métodos de difusión por disco, microdilución y bioautografía. Los ensayos de sytox y cometa fueron utilizados para evaluar el mecanismo de acción. De esta forma, se detectaron nueve compuestos fenólicos en el extracto de $T$. lucida. El extracto exhibió actividad solo en $S$. aureus (MIC de $4.000 \mathrm{mg} / \mathrm{ml}$ ). La bioautografía reveló que los compuestos fenólicos podrían actuar sinérgicamente. Las pruebas de sytox y cometa mostraron una acción antibacteriana del extracto sobre la membrana bacteriana y el ADN de esta cepa bacteriana.

Palabras clave: Tagetes lucida Cav.; Composición química; Efecto antibacteriano; Sitio de acción

Recibido | Received: August 28, 2019

Aceptado | Accepted: November 14, 2019

Aceptado en versión corregida | Accepted in revised form: April 10, 2020

Publicado en línea | Published online: November 30, 2020

Este artículo puede ser citado como / This article must be cited as: PY Villa-Silva, A Iliná, JA Ascacio-Valdés, SC Esparza-González, LE Cobos-Puc, R Rodríguez-Herrera, SY Silva-Belmares. 2020 Phenolic compounds of Tagetes lucida Cav. with antibacterial effect due to membrane damage. Bol Latinoam Caribe Plant Med Aromat 19 (6): 580 - 590. https://doi.org/10.37360/blacpma.20.19.6.41 


\section{INTRODUCTION}

Compositae (Asteraceae) includes a large number of species with an antimicrobial effect such as Tagetes lucida, Calendula stellata, Calendula officinalis, Calendula arvensis, and Eclipta postrate (Lehbili et al., 2017; Lovecka et al., 2017; Abudunia et al., 2017; Chung et al., 2017). The genus Tagetes includes 56 species, and in some species flavonoids, anthocyanins, and terpenes have been detected (Shahzadi \& Shah, 2015; Cicevan et al., 2016; Gakuubi et al., 2016). For years it has been shown that some Compositae species act against strains of medical importance such as Enterococcus fecalis (Lehbili et al., 2017) and Salmonella typhi (Karthikumar et al., 2007). Recently, has been detected an antibacterial effect of the essential oil of Tagetes minuta against Staphylococcus aureus, Enterobacter cloacae, Mycobacterium smegmatis, Listeria ivanovii, Streptococcus uberis, Vibrio spp and Escherichia coli (Igwaran et al., 2017), as well as antibacterial action of the extracts (butanol and ethyl acetate) from T. minuta on Micrococcus luteus, $S$. aureus, Bacillus subtilis and Pseudomonas pikettii. In these sense, it has been shown that flavonols are the bioactive compounds responsible for the antibacterial effect on M. luteus (Shahzadi \& Shah, 2015). On the other hand, antibacterial action of Tagetes patula and Tagetes erecta against E. coli, Pastrulla multocida, B. subtilis and $S$. aureus has been confirmed (Ayub et al., 2017).

Tagetes lucida Cav. is an aromatic plant known as hierbanis, has been used since pre-hispanic times as a remedy to treat stomach diseases (GarcíaSánchez et al., 2012; Bonilla-Jaime et al., 2015). This plant grows in Guatemala, Honduras, and northern Mexico (Shahzadi \& Shah, 2015; Cicevan et al., 2016). Seven coumarins, 7,8-dihydroxycoumarin, umbelliferone (7-hydroxycoumarin), scoparona $(6,7-$ dimethoxy-coumarin), esculetin (6,7-dihydroxycoumarin), 6-hydroxy-7-methoxycoumarin, herniaryne (7-methoxycoumarin) and scopoletin (6-methoxy7-hydroxycoumarin), and three flavonoids, patuletina, quercetin and quercetagetin have been identified in the extracts of $\mathrm{CH}_{2} \mathrm{Cl}_{2}$ and $\mathrm{MeOH}$ from aerial parts of T. lucida (Céspedes et al., 2006). Dihydroxylated coumarins present in both extracts display antibacterial effects against $B$. subtilis, $E$. coli, Proteus mirabilis, Klebsiella pneumoniae, Salmonella typhi, Salmonella sp., Shigella boydii, Shigella sp., Enterobacter aerogenes, Enterobacter agglomerans, Sarcina lutea, Staphylococcus epidermidis, S. aureus, Yersinia enterolitica and
Vibrio cholerae (Céspedes et al., 2006). Notwithstanding, 5,7,4'-trimethoxyflavone from ethyl acetate extracts of $T$. lucida displays activity against $S$. boydii, $S$. aureus, $S$. epidermidis, Pseudomonas aeruginosa, B. subtilis, Sarcina lutea and four strains of $V$. cholerae (Hernández et al., 2006).

These shreds of evidence indicate that the compounds related to the antimicrobial effect of $T$. lucida depend on the solvent used for their extraction. Here, it should be highlighted that extracts commonly used in traditional remedies are ethanolic extracts. However, the chemical composition, as well as their antibacterial action and mechanism of action of this extract from T. lucida are unknown (Moussaoui et al., 2010; Regalado et al., 2011). Besides, in recent years, an increase in microbial resistance has been reported worldwide (Riva et al., 2015; Day et al., 2017; Pagliano et al., 2016). For this reason, the identification of new source of antimicrobial drugs is imperative. T. lucida could represent a potential source of antibacterial bioactive compounds (Lenza et al., 2009). Therefore, the aim of the present work was to identify the main compounds of the ethanolic extract of $T$. lucida and evaluate the antibacterial effect and sites of action on pathogenic bacteria of clinical importance.

\section{MATERIAL AND METHODS Plant material and extraction}

T. lucida Cav. (aerial part) was collected in Saltillo, Coahuila, Mexico, (latitude 25.421391 and longitude -101,000237) during February 2016. A specimen of the plant was registered in the Herbarium of the Autonomous University of Nuevo León with number 030054. The plant was dried at room temperature and ground in a mill (STAR Tisamatic-mill) to obtain a powder with particles of approximately $600 \mu \mathrm{m}$. Then, the extraction was carried out with constant agitation for 2 hours using a stirring plate (Hotplate Fisher Scientific) with $10 \% \mathrm{w} / \mathrm{v}$ ethanol at room temperature $\left(25^{\circ} \mathrm{C}\right)$. The extract was filtered with a Whatman \#4 paper and clarified with a Whatman G/FA glass microfibre filters. The clarified extract dried on a rotary evaporator (Büchi R-120) at $35{ }^{\circ} \mathrm{C}$, then recovered, and the percentage yield calculated by gravimetric analysis using an analytical balance (Ohaus N1B110 Navigator) (Hernández-Ocura et al., 2017). The yield was calculated in triplicate from the weight of the plant powder. Finally, the extract was stored at $-5^{\circ} \mathrm{C}$ until use. 


\section{Chemical characterization by Rp-HPLC-MS}

The compounds contained in the ethanolic extract of T. lucida were identified by high-resolution reverse phase liquid chromatography (RP-HPLC-ESI-MS) using a method adapted for phenolic compounds. Briefly, an HPLC chromatograph (Varian) was used. The equipment includes an autosampler (Varian Pro Star 410, USA), a ternary pump (Varian Pro Star 230I, USA) and a PDA detector (Varian Pro Star 330, USA). An ion trap mass spectrometer as detector (Varian 500-MS IT Mass Spectrometer, USA) equipped with an electrospray ionization source. First, a solution of the extract at $1000 \mu \mathrm{g} / \mathrm{ml}$ in ethanol was prepared and filtered through a $0.45 \mu \mathrm{m}$ nylon membrane. The compounds of T. lucida extract were separated on a Denali C18 column $(150 \mathrm{~mm} x$ $2.1 \mathrm{~mm}, 3 \mu \mathrm{m}$, Grace, USA), after injection of $5 \mu \mathrm{l}$ of extract. The oven temperature was maintained at $30^{\circ} \mathrm{C}$.

The elution was carried out with a gradient of formic acid $(0.2 \%, \mathrm{v} / \mathrm{v}$, solvent $\mathrm{A})$ and acetonitrile (solvent B). As an initial gradient, 97\% A and 3\% B added for 0-5 min, then a linear gradient of $91 \% \mathrm{~A}$ and $9 \% \mathrm{~B}$ for 5-15 min, followed by a linear gradient of $84 \% \mathrm{~A}$ and $16 \%$ of $\mathrm{B}$ for $15-45 \mathrm{~min}$ and ending with a linear gradient of $50 \% \mathrm{~A}$ and $\mathrm{B}$. The column was then washed and reconditioned. The flow rate was maintained at $0.2 \mathrm{ml} / \mathrm{min}$. The compounds were monitored at 245, 280, 320, and $550 \mathrm{~nm}$ during the elution and detected at $280 \mathrm{~nm}$. The fractions eluted injected into the source of the mass spectrometer without splitting automatically. The mass spectra were acquired in the negative ion mode $[\mathrm{M}-\mathrm{H}]^{-1}$ to obtain the $\mathrm{m} / \mathrm{z}$ of each compound. Nitrogen was used as nebulizing gas and helium as damping gas. The ion source parameters were: spray voltage $5.0 \mathrm{kV}$, and capillary voltage and temperature were $90.0 \mathrm{~V}$ and $350^{\circ} \mathrm{C}$, respectively. Data were collected and processed using MS Workstation software (V 6.9). The compounds were identified according to the retention times and on the interpretation of the $\mathrm{m} / \mathrm{z}$ stored in the chromatographic database. Additionally, the identification was supported by information previously reported in the literature (Guajardo-Rios et al., 2017)

\section{Antibacterial activity evaluation Bacterial strains}

Antibacterial effect of the ethanolic extract from $T$. lucida was tested on S. aureus (ATCC 6538), E. coli (ATCC 11229), P. aeruginosa (ATCC 15442) and
Salmonella choleraesuis (ATCC 1070) strains provided by the Faculty of Chemistry of the Autonomous University of Coahuila. The above strains were kept at $4^{\circ} \mathrm{C}$ on Mueller Hinton agar (Bioxon ${ }^{\circledR}$ ). From each strain, a bacterial suspension of $1 \times 10^{6}$ colony forming units $(\mathrm{CFU} / \mathrm{ml})$ as prepared using the Mc Farland scale of 0.5 using MuellerHinton broth. Bacterial suppression of each strain was used in disc diffusion test, minimum inhibitory concentration (MIC), bioautography, sytox green, and comet assays.

\section{Disk diffusion test}

This test was carried out on Petri dishes prepared with Mueller-Hinton agar under aseptic conditions. In each plate, $100 \mu$ of the microbial suspension of each strain was inoculated and distributed using a Drigalski handle. On the inoculated Petri dishes were placed $7 \mathrm{~mm}$ diameter filter paper discs previously impregnated with $10 \mu \mathrm{l}$ of the extract at $2.000 \mathrm{mg} / \mathrm{ml}$ (Bauer et al., 1966, Silva-Belmares et al., 2014). 10 $\mathrm{ml}$ of ceftriaxone $(4.000 \mathrm{mg} / \mathrm{ml})$ and ethanol $(10 \%)$ were used as positive and negative controls, respectively. Petri dishes incubated for $24 \mathrm{~h}$ at $37^{\circ} \mathrm{C}$ and the inhibition zone was measured using a Vernier. The most sensitive strains were used to evaluate the MIC, bioautography, the sytox method and comet assay.

\section{Minimal inhibitory concentration (MIC)}

The minimum inhibitory concentration was measured by the broth microdilution method in a 96-well plate (Klancnik et al., 2010). Both the extract and the positive control (ceftriaxone) were tested at 0.003 , $0.008,0.015,0.031,0.062,0.125,0.250,0.500$, $1.000,2.000$ and $4.000 \mathrm{mg} / \mathrm{ml}$. Therefore, from both samples, serial dilutions $(100 \mathrm{ml})$ were made from a stock solution of $8,000 \mathrm{mg} / \mathrm{ml}$, and Mueller Hinton broth was tested as a negative control. Just then, 100 $\mu \mathrm{l}$ of a bacterial suspension of $1 \times 10^{6} \mathrm{CFU} / \mathrm{ml}$ was added. The microplates incubated at $37^{\circ} \mathrm{C}$ for $24 \mathrm{~h}$, and the absorbance measured at $625 \mathrm{~nm}$ in a microplate reader (BioTek Synergy HTX MultiMode Reader).

\section{Bioautography}

The antibacterial effect of the T. lucida extract fractions was evaluated by bioautography, as they contained a mixture of compounds. For this, a thin layer chromatography (TLC) of the extract of $T$. lucida was used. Briefly, the extract at $2.000 \mathrm{mg} / \mathrm{ml}$ 
was applied on a $25 \times 75 \mathrm{~mm}$ silica gel plate and eluted with petroleum ether:ethyl acetate (2:1) in an elution chamber. The retention factor (Rf) was measured to identify each fraction. Then, the TLC was placed in a Petri dish under aseptic conditions, covered with a layer of Mueller-Hinton agar and inoculated with $100 \mu \mathrm{l}$ of a $1 \times 10^{6} \mathrm{CFU} / \mathrm{ml}$ bacterial suspension. The petri dish incubated during $24 \mathrm{~h}$ at $37^{\circ} \mathrm{C}$ and the antibacterial fractions identified by a zone of inhibition of bacterial growth. The test was carried out in triplicate.

\section{Analysis of mechanism of action Effect on the bacterial membrane}

Damage to the bacterial membrane was detected qualitatively with a specific dye known as Sytox green. According to the results of CMI, we evaluated the effect of the extract at 1,000, 2,000, and 4,000 $\mathrm{mg} / \mathrm{ml}$ in a 96 -well microplate. Therefore, $100 \mu \mathrm{L}$ of each concentration and $100 \mu \mathrm{L}$ of a microbial suspension at $1 \times 10^{6} \mathrm{CFU} / \mathrm{ml}$ were added per well. Mueller-Hinton culture broth tested as a negative control and Triton X-100 as a positive control. After $24 \mathrm{~h}$ of incubation at $37^{\circ} \mathrm{C}, 5 \mathrm{ml}$ of Sytox ${ }^{\circledR}$ green dye $(1 \mathrm{mM})$ was added to each treatment (nucleic acid staining, Cat. No. S7020) (Diaz et al., 2018) and incubated in the dark for $30 \mathrm{~min}$. Both the bacteria treated with the extract of T. lucida and those treated with the positive and negative controls were observed by optical microscopy in a bright field and fluorescent at 100x using a microscope (AxioLab A1 Carl Zeiss, China).

\section{Effect on the bacterial DNA}

The effect on DNA was evaluated by the comet assay. The plates for the comet test $(2.5 \times 7)$ were covered with the Comet Oxiselect Kit agarose gel (free of additives) and kept their cavities free. Then, in each cavity, $75 \mu \mathrm{l}$ of the gel contained in each deposited sample was added. The plates were stored at $4^{\circ} \mathrm{C}$ for $30 \mathrm{~min}$ to maintain solidification. The plate covered with a lysis buffer $(\mathrm{pH} 10)$ was incubated at $4^{\circ} \mathrm{C}$ for $10 \mathrm{~h}$ in a dark room. The lysis buffer was replaced by an enzyme buffer. Every plate was incubated at $37^{\circ} \mathrm{C}$ during $2 \mathrm{~h}$ (in a dark room), and then buffer removed. The plate was placed in a chamber for electrophoresis and covered with a running buffer. During electrophoresis, 12 volts were applied for $60 \mathrm{~min}$. The electrophoresis gel was washed three times with distilled water for $2 \mathrm{~min}$ and then washed with $70 \%$ ethanol for $10 \mathrm{~min}$. Then, the Vista-Green DNA dye was stained with $0.5 \mu \mathrm{l}$ and observed at $100 \mathrm{x}$ under a fluorescence microscope (AxioLab A1 Carl Zeiss, China) (Solanky \& Haydel, 2012; Min-Jeong et al., 2016).

\section{Statistical analysis}

All results were expressed as the mean and the standard deviation $(\mathrm{n}=3)$. Statistical comparison of disc diffusion and MIC data were performed with an analysis of variance (ANOVA) followed by post hoc test of Tukey. Statistical significance was accepted at $p<0.05$.

\section{RESULTS AND DISCUSSION Plant material and extraction}

The ethanolic extract of $T$. lucida showed a yield of $7.3 \pm 0.01 \%$ that resembles the extracts of other Compositae (García-Pérez et al., 2016). The ethanolic extract of $T$. lucida showed a yield percent similar to the methanolic extract since they have chemical compounds with comparable polarities (Téllez-López et al., 2013).

\section{Chemical characterization by Rp-HPLC-MS}

The Rp-HPLC study detected medioresinol (1); 3,4DHPEA-EA (2); gardenina B (3); tangeretin (4); 6 "O-acetylglycine (5), petunidine 3,5-O-diglucoside (6), 4-O-glycoside of gallic acid (7), tartaric caffeic acid (8) and sculin (9), in the ethanolic extract (Figure No. 1) which have not been previously identified in T. lucida However, the extract could contain compounds not detected by this method and/or chromatographic column. For instance, phenolic compounds with antimicrobial effect have been detected in some organic extracts of T. lucida $\left(\mathrm{CH}_{2} \mathrm{Cl}_{2}, \mathrm{MeOH}\right.$, and ethyl acetate) (Céspedes et al., 2006; Hernández et al., 2006). In the present study, essential oils were not detected in the ethanolic extract since they could have been removed during drying of the extract by rotary evaporation. Still, other extracts from $T$. lucida contain essential oils such as estragole, methylenenolol, anethole (Bicchi et al., 1997), chavicol (Cicció, 2004), eugenol and myrcene (De la Luz et al., 2011).

\section{Antibacterial activity evaluation Disk diffusion test}

The ethanolic extract of $T$. lucida inhibited the growth of $S$. aureus with a zone of inhibition of 11.50 $\pm 0.20 \mathrm{~mm}$. However, it did not affect the growth of $E$. coli, S. choleraesius and $P$. aeruginosa. As we expected, ceftriaxone inhibited the growth of all microorganisms tested with a zone of inhibition $\geq 30$ 


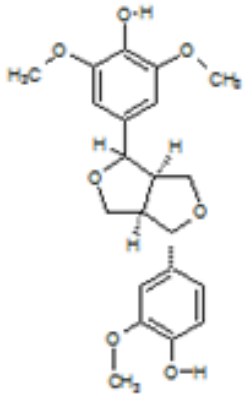

(1)

$\operatorname{tr}(\min )=2.489$

$\mathrm{m} / \mathrm{z}[\mathrm{m}-\mathrm{H}]=387$

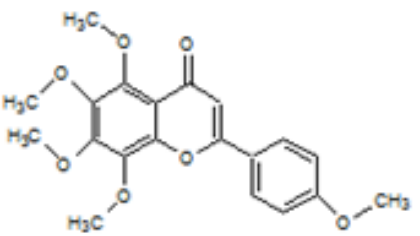

(4)

$$
\begin{gathered}
\operatorname{tr}(\min )=27.657 \\
\mathrm{~m} / \mathrm{z}[\mathrm{m}-\mathrm{H}]^{*}=371.2
\end{gathered}
$$

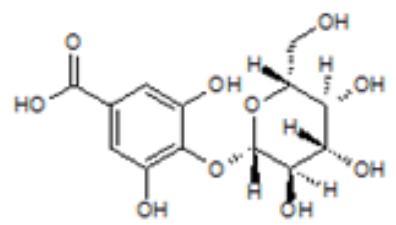

(7)

$$
\begin{aligned}
& \mathrm{tr}(\min )=38.411 \\
& \mathrm{~m} / \mathrm{z}[\mathrm{m}-\mathrm{H}]^{-}=331
\end{aligned}
$$

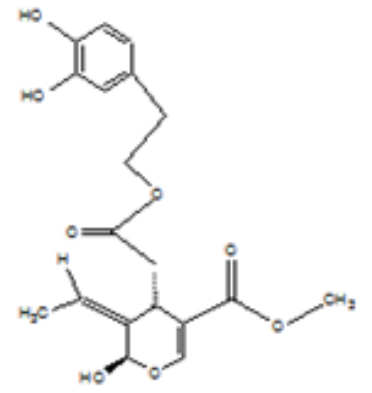

(2)

$$
\begin{gathered}
\operatorname{tr}(\min )=2.555 \\
\mathrm{~m} / \mathrm{z}[\mathrm{m}-\mathrm{H}]^{-}=377.1
\end{gathered}
$$<smiles>COc1cc2c(=O)c(-c3ccc(O)cc3)coc2cc1OC1OC(COC(C)=O)=C(O)C(O)=C1O</smiles>

(5)

tr $(\min )=28.733$

$\mathrm{m} / \mathrm{z}[\mathrm{m}-\mathrm{H}]^{*}=487.3$<smiles>O=C(O)[C@@H](O)[C@@](O)(C(=O)O)C(=O)/C=C/c1ccc(O)c(O)c1</smiles>

(8)

$$
\begin{gathered}
\operatorname{tr}(\min )=47.306 \\
\mathrm{~m} / \mathrm{z}[\mathrm{m}-\mathrm{H}]^{-}=311.2
\end{gathered}
$$<smiles>COc1ccc(-c2cc(=O)c3c(O)c(OC)c(OC)c(OC)c3o2)cc1</smiles>

(3)

$\operatorname{tr}(\min )=25.547$

$\mathrm{m} / \mathrm{z}[\mathrm{m}-\mathrm{H}]^{\circ}=357.1$<smiles>COc1cc(-c2cc3c(OC4OC(CO)C(O)C(O)C4O)cc(O)cc3cc2OC2OC(CO)C(O)C(O)C2O)cc(OC)c1O</smiles>

(6)

$\operatorname{tr}(\min )=30.612$

$\mathrm{m} / \mathrm{z}[\mathrm{m}-\mathrm{H}]^{*}=641.1$<smiles>O=c1ccc2cc(OC3O[C@H](CO)[C@@H](O)[C@H](O)C3O)c(O)cc2o1</smiles>

(9)

$\operatorname{tr}(\min )=51.804$

$\mathrm{m} / \mathrm{z}[\mathrm{m}-\mathrm{H}]^{\prime}=339.2$

Figure No. 1

Chemical structures detected in the ethanolic extract from Tagetes lucida Cav. by Rp-HPLC-MS 
mm, while negative control did not show inhibitionzones. Our results are similar to those of the methanolic extract of T. lucida, since it gives rise to zones of $10 \mathrm{~mm}$ inhibition (Vega-Menchaca, 2013). On the other hand, zones of inhibition $\geq 9 \mathrm{~mm}$ of the ethanolic extract of T. lucida on S. typhi, Salmonella enteritidis, E. coli, Shigella dysenteriae and Shigella flexneri were detected (Capunzo et al., 2003), while the extract in $\mathrm{MeOH} / \mathrm{CH}_{2} \mathrm{Cl}_{2}(1: 4)$ at $0.4 \mu \mathrm{g} / \mathrm{disc}$ inhibited the growth of $E$. coli and Proteus mirabilis by $40 \%$, K. pneumoniae by $31.1 \%$, Salmonella $s p$. in $35.5 \%$ at $72 \mathrm{~h}$ of cultivation (Céspedes et al., 2006). The essential oil of $T$. lucida reduced the growth of $S$. aureus with zones of inhibition of $17 \mathrm{~mm}$, as well as of $E$. coli and B. subtilis with zones of inhibition of $14 \mathrm{~mm}$ (Elsayed et al., 2015).

\section{Minimal inhibitory concentration (MIC)}

Table No. 1 shows the percentages of inhibition of the extracts from T. lucida on S. aureus, which was the only strain sensitive to this treatment. Here, it should be highlighted that the antibacterial action was dependent on the concentration used since lower doses to $1.000 \mathrm{mg} / \mathrm{ml}$ did not inhibit bacterial growth (data not shown). However, inhibited bacterial growth in a $61 \pm 1.73,93.00 \pm 1.00$, and $100.00 \pm$ $0.00 \%$ at $1.000,2.000$, and $4.000 \mathrm{mg} / \mathrm{ml}$, respectively. In this way, the MIC of the ethanolic extract of T. lucida on $S$. aureus was $4.000 \mathrm{mg} / \mathrm{ml}$ $\left(\mathrm{MIC}_{100}\right)$. Accordingly, with the above, other Compositae species have a MIC of $1 \mathrm{mg} / \mathrm{ml}$ against S. aureus (Tereshuk et al., 1997; Capunzo et al., 2003; Hernández et al., 2006). Interestingly, the MIC values were 100 and $200 \mathrm{mg} / \mathrm{ml}$ on Campylobacter jejuni (UVG 62-1773-6), and $450 \mathrm{mg} / \mathrm{ml}$ on $E$. coli (ATCC 25922), Aeromonas hominis (ATCC 7966), and $P$. aeruginosa (27853) for the methanolic and chloroform extract from $T$. lucida suggesting that the MIC values depend on both the chemical composition of each extract and the bacterial susceptibility. Furthermore, ceftriaxone (MIC of $\leq$ $0.003 \pm 0.000 \mathrm{mg} / \mathrm{ml}$ ) exhibited a higher potency than the ethanolic extract from $T$. lucida.

Table No. 1

Percentages of bacterial inhibition of the ethanolic extract from Tagetes lucida Cav. on Staphylococcus aureus

\begin{tabular}{cc}
\hline Concentration $\mathbf{~ m g / m l}$ & Bacterial inhibition (\%) \\
\hline 1.000 & $61.00 \pm 1.73$ \\
2.000 & $93.00 \pm 1.00$ \\
4.000 & $100.00 \pm 0.00$ \\
\hline
\end{tabular}

The data are expressed as the mean \pm standard deviation, $n=3$

\section{Bioautography}

The eluent of petroleum ether-ethyl acetate (2:1) separated the fractions of the extract of T. lucida better other eluents since the retention factor between the bands was $(\mathrm{Rf}) \geq 0.1$. Therefore, it was more efficient, as previously reported by Wagner \& Bladt (2001). In these conditions, five fractions of ethanolic extract from $T$. lucida with $\mathrm{Rf}$ values of $0.50,0.67$, $0.75,0.80$, and 0.95 were separated by TLC. JuárezSánchez (2015) separated three fractions after degreasing the plant with hexane with similar $\mathrm{Rf}$ values (Rf of $0.50,0.68$, and 0.77 ), indicating that the extraction procedure influences the fractions obtained from an extract determined due to its chemical composition (Dewanjee et al., 2015).

The fractions evaluated by bioautography did not have an antibacterial effect. Here, can be argued that the antibacterial effect on $S$. aureus of the extract from $T$. lucida could be due to a synergism between the five fractions based in that: 1) the antibacterial effect of the extract was observed in diffusion assay, and 2) it has been observed that other fractions or compounds display synergistic antibacterial effects (Silva-Belmares et al., 2014; Jesionek et al., 2015; Zater et al., 2016). On the other hand, another explanation for this observation is that the stationary phase retained the compounds containing in the five fractions, so they did not migrate to the culture medium to exert their antibacterial effect. In any case, future experiments using isolated fractions are warranted.

\section{Target action evaluation}

Because the ethanolic extract from T. lucida only inhibited the growth of $S$. aureus in the test of disc diffusion plate and microdilution, the strain was used to determine the site of action through the Sytox Green test (plasmatic membrane) and comet assay 
(bacterial DNA). The Sytox green test showed that the ethanolic extract from $T$. lucida permeabilizes the membrane (observed as fluorescence) of Staphylococcus aureus in a concentration-dependent manner $(1.000$ and $2.000 \mathrm{mg} / \mathrm{ml})$. The group treated with the negative control showed no fluorescence because its membrane remains intact (Figure No. 2).

The microscopic observations indicate that the ethanolic extract from $T$. lucida causes the formation of pores in the bacterial membrane because the fluorogenic dye (Sytox Green) only penetrates the compromised membranes and fluoresces when it binds to DNA (Kim et al., 2015). The effect on the plasma membrane resembles the reported by (Lee $e t$ al., 2015). The effect of the extract in $S$. aureus could be due to some phenolic compounds detected by Rp-
HPLC-MS since phenolic groups affect the stability of membrane proteins through the formation of pores resulting in bacterial death (Ye et al., 2011; Casero et al., 2013; Diaz et al., 2018).

On the other hand, the ethanolic extract from T. lucida breaks the bacterial deoxyribonucleic acid (DNA) because the bacteria embedded in the agarose and subjected to electrophoresis gave rise to the formation of a comet-like structure observed by fluorescence microscopy. The comet assay is specific to assess the decomposition of the DNA chain (Solanky \& Haydel, 2012) because the fluorescence intensity of the tail relative to the comet's head is a reflection of DNA breakage since comets are formed by breaking the DNA loops (see Figure No. 3).

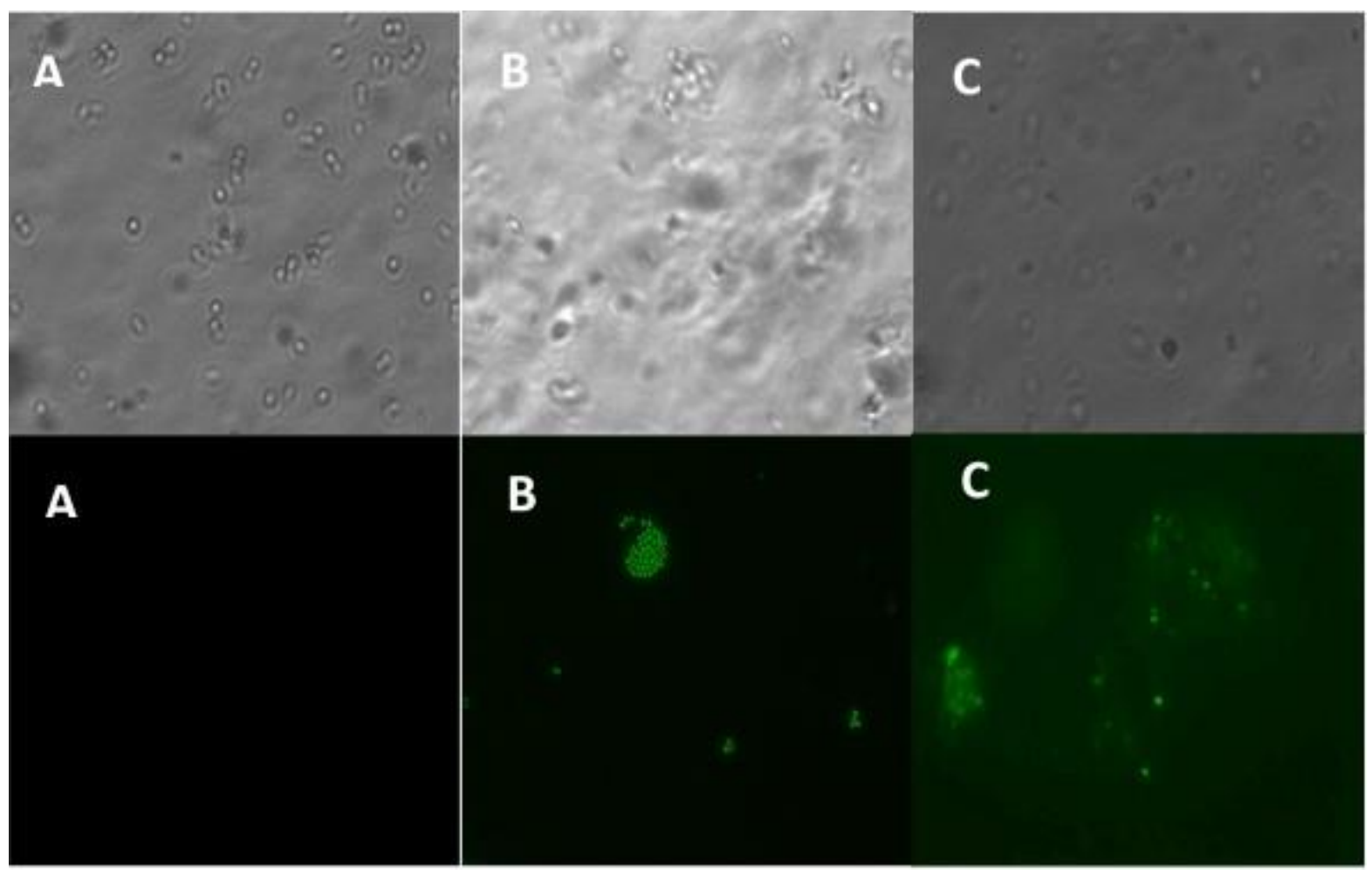

Figure No. 2

Effect of the ethanolic extract from $T$. lucida on the $S$. aureus bacterial membrane detected by SYTOX Green absorption. In the upper panels, the images observed correspond to optical microscopy (100x). In the lower panels, the images observed correspond to fluorescent field microscopy (100x). Panel A shows the bacteria treated with the negative control. Panel B shows the strain treated with the ethanolic extract from $T$. lucida at $1 \mathrm{mg} / \mathrm{ml}$. Panel C shows the strain treated with the ethanolic extract from $T$. lucida at $2 \mathrm{mg} / \mathrm{mL}$ 


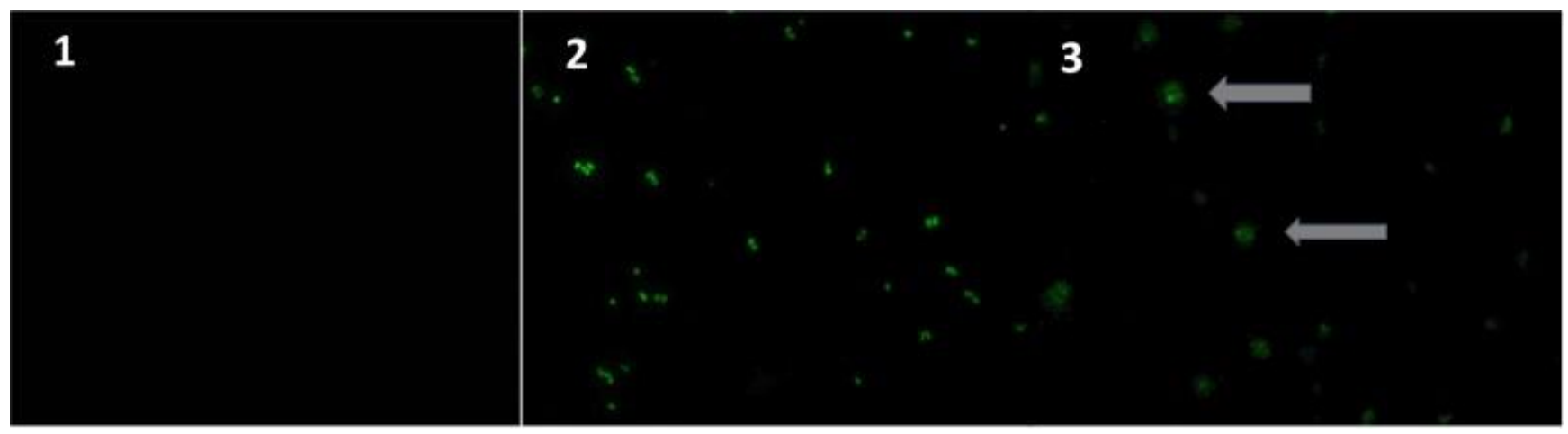

Figure No. 3

Effect of the ethanolic extract from T. lucida on the bacterial DNA detected by the comet assay. Panel 1 shows the control with an ethanolic extract from Tagetes lucida Cav. without Staphylococcus aureus. Panel 2 shows control with $S$. aureus without extract. Panel 3 shows the ethanolic extract from T. lucida against $S$. aureus

It has been shown that 3,4-DHPEA-EA inhibits the growth of $S$. aureus with MIC values between 125 and $250 \mu \mathrm{g} / \mathrm{ml}$ (Bisignano et al., 2014), whereas medioresinol does at $5.0 \mu \mathrm{g} / \mathrm{mL}$ (Hwang et al., 2013). Tangeretin has a biopreservative potential so that it could also be involved in the antibacterial effect of the ethanolic extract from $T$. lucida (Jayaprakasha et al., 2000). Additionally, 3,4DHPEA-EA and tyrosol show antioxidant activity (Masella et al., 1999), so they have an anti-aging property (Nianhan et al., 2014), while, tangeretine acts as a suppressant for breast cancer (Lakshmi \& Subramanian, 2014). As well, coumarins have been detected in some extracts from flowers, leaves, and stems of T. lucida (Mejia-Barajas et al., 2012; TéllezLópez et al., 2013). All the compounds detected in the extract of T. lucida have a polyphenolic chemical structure. Therefore, they could destabilize plasma membranes to cause microbial death, as some flavonoids are known to cause cell membrane damage (Lee et al., 2015).

\section{CONCLUSION}

The present study shows that the ethanolic extract from $T$. lucida has an antibacterial effect against $S$. aureus. This antibacterial action of $T$. lucida is related to membrane disruption and DNA damage, probably induced by phenolic compounds contained in this plant. On this basis, T. lucida represents a potential source of antibacterial compounds that could be used for the development of pharmaceutical products against $S$. aureus.

\section{REFERENCES}

Abudunia AM, Marmouzi I, Faouzi ME, Ramli Y, Taoufik J, El Madani N, Essassi EM, Salama A, Khedid K, Ansar M, Ibrahimi A. 2017. Anticandidal, antibacterial, cytotoxic and antioxidant activities of Calendula arvensis flowers. J Mycol Med 27: 90 - 97. https://doi.org/10.1016/j.mycmed.2016.11.002

Ayub A, Hussain AI, Hanif MA, Chatha SAS, Kamal GM, Shahid M, Jannehf O. 2017. Variation in phenolic profile, $\beta$-Carotene and flavonoid contents, biological activities of two tagetes species from Pakistani flora. Chem Biodivers 14: 1 - 8. https://doi.org/10.1002/cbdv.201600463

Bauer AW, KirbyWM, Sherris JC, Turck, M, 1966. Antibiotic susceptibility testing by a standardized single disk method. Am J Clin Pathol 45: 493 - 496. https://doi.org/10.1093/ajcp/45.4_ts.493

Bicchi C, Fresia M, Rubiolo P, Monti D, Franz C, Goehler I. 1997. Constituents of Tagetes lucida Cav. ssp. lucida essential oil. J Flavour Frag 12: 47 - 52.

https://doi.org/10.1002/(sici)1099-1026(199701)12:1<47::aid-ffj610>3.3.co;2-z

Bisignano C, Filocamo A, Ginestra G, Giofre' SV, Navarra M, Romeo R, Mandalari G. 2014. 3,4-DHPEA-EA from Olea europaea L. is effective against standard and clinical isolates of Staphylococcus sp. Ann Clin Microbiol Antimicrob 13: 24. https://doi.org/10.1186/1476-0711-13-24

Bonilla-Jaime H, Guadarrama-Cruz G, Alarcon-Aguilar FJ, Limón-Morales O, Vazquez-Palacios G. 2015. Antidepressant-like activity of Tagetes lucida Cav. is mediated by 5-HT1A and 5-HT2A receptors. J Nat 
Med 69: 463 - 470. https://doi.org/10.1007/s11418-015-0909-5

Capunzo M, Brunetti L, Cavallo P, Boccia G, De Caro F, Leluzzi M. 2003. Antimicrobial activity of dry extracts of Tagetes lucida from Guatemala. J Prev Med Hyg 44: 85 - 87.

Casero C, Estévez-Braun A, Ravelo AG, Demo M, Méndez-Álvarez S, Machín F. 2013. Achyrofuran is an antibacterial agent capable of killing methicillin-resistant vancomycin-intermediate Staphylococcus aureus in the nanomolar range. Phytomedicine 20: 133 - 138. https://doi.org/10.1016/j.phymed.2012.11.003

Céspedes C, Ávila J, Martínez A, Serrato B, Caldero J, Múgica A, Salgado-Garciglia R. 2006. Antifungal and antibacterial activities of Mexican tarragon (Tagetes lucida). Agric Food Chem 54: 3521 - 3527. https://doi.org/10.1021/jf053071w

Cicció JF. 2004. A source of almost pure methyl chavicol: volatile oil from the aerial parts of Tagetes lucida (Asteraceae) cultivated in Costa Rica. Rev Biol Trop 52: 853 - 857.

Cicevan R, Hassan MAl, Sestras AF, Prohens J, Vicente O, Sestras RE, Boscaiu M. 2016. Screening for drought tolerance in cultivars of the ornamental genus Tagetes (Asteraceae). Peer J 4: e2133. https://doi.org/10.7717/peerj.2133

Chung IM, Rajakumar G, Lee JH, Kim SH, Thiruvengadam M. 2017. Ethnopharmacological uses, phytochemistry, biological activities, and biotechnological applications of Eclipta prostrata. Appl Microbiol Biotechnol 101: 5247 - 5257. https://doi.org/10.1007/s00253-017-8363-9

Day M, Doumith M, Jenkins C, Dallman TJ, Hopkins KL, Elson R, Godbole G, Woodford N. 2017. Antimicrobial resistance in Shiga toxin-producing Escherichia coli serogroups O157 and O26 isolated from human cases of diarrhoeal disease in England. J Antimicrob Chemother 72: 145 - 152. https://doi.org/10.1093/jac/dkw371

De la Luz LA, Hechevarría-Sosa I, Rodríguez Ferradá C, Milanés Figueredo M. 2011. Optimal time for cultivation and harvesting of Tagetes lucida Cav. Rev Cub Plant Med 16: 201 - 208.

Dewanjee S, Gangopadhyay M, Bhattacharya N, Khanra R, Dua TK. 2015. Bioautography and its scope in the field of natural product chemistry. J Pharm Anal 5: 75 - 84. https://doi.org/10.1016/j.jpha.2014.06.002

Díaz ME, Rocha GF, Kise F, Rosso AM, Guevara MG, Parisi MG. 2018. Antimicrobial activity of an aspartic protease from Salpichroa origanifolia fruits. Lett Appl Microbiol 67: 168 - 174. https://doi.org/10.1111/lam.13006

Elsayed AO, Saber F.H, Azza MN El-Deen, Fayez NZ, Mahfouz M. Abd-Elgawad, Awaad MK. 2015. Some biological activity of Tagetes lucida plant cultivated in Egipt. Adv Environ Biol 9: 82 - 88.

Gakuubi MM, Wagacha JM, Dossaji SF, Wanzala W. 2016. Chemical composition and antibacterial activity of essential oils of Tagetes minuta (Asteraceae) against selected plant pathogenic bacteria. Int J Microbiol 2016: 7352509. https://doi.org/10.1155/2016/7352509

García-Pérez JS, Cuéllar-Bermúdez SP, Arévalo-Gallegos A, Rodríguez-Rodríguez J, Iqbal HM, Parra-Saldivar R. 2016. Identification of bioactivity, volatile and fatty acid profile in supercritical fluid extracts of Mexican arnica. Int J Mol Sci 17: E1528. https://doi.org/10.3390/ijms17091528

García-Sánchez F, López-Villafranco Ma, Aguilar-Rodríguez S, Aguilar-Contreras A. 2012. Ethnobotany and comparative morpho-anatomy of Tagetes used in Nicolas Romero, State of Mexico. Bot Sci 90: 221 - 232. https://doi.org/10.17129/botsci.388

Guajardo-Ríos O, Lozano-Cabazos CJ, Valdez-Aguilar LA, Benavides-Mendoza A, Ibarra-Jiménez L, AscacioValdès JA, Aguilar-Gonzàlez CN. 2017. Animal-based organic nutrition can substitute inorganic fertigation in soiless-grown grape tomato. Acta Agric Scand B Soil Plant Sci 68: 77 - 85. https://doi.org/10.1080/09064710.2017.1367030

Hernández-Ocura L, Carranza-Rosales P, Cobos Puc LE, López-López LI, Ascasio-Valdès JA, Silva-Belmares SY. 2017. Bioguided fractionation from Solanum elaeagnifolium to evaluate toxicity on cellular lines and breast tumor explants. Vitae 24: 124 - 131. https://doi.org/10.17533/udea.vitae.v24n2a05

Hernández T, Canales M, Flores C, García AM, Duran A, Avila JG. 2006. Antimicrobial Activity of Tagetes lucida. Pharm Biol 44: 19 - 22. https://doi.org/10.1080/13880200500509157

Hwang JH, Choi H, Hwang IS, Kim AR, Woo ER, Lee DG. 2013. Synergistic antibacterial and antibiofilm effect between (+)-medioresinol and antibiotics in vitro. Appl Biochem Biotechnol 170: 1934 - 1941. https://doi.org/10.1007/s12010-013-0351-7 
Igwaran A, Iweriebor BC, Okoh SO, Nwodo UU, Obi LC, Okoh AI. 2017. Chemical constituents, antibacterial and antioxidant properties of the essential oil flower of Tagetes minuta grown in Cala community Eastern Cape, South Africa. BMC Complement Altern Med 17: 351. https://doi.org/10.1186/s12906-017-1861-6

Jayaprakasha GK, Negi PS, Sikder S, Rao LJ, Sakariah KK. 2000. Antibacterial activity of Citrus reticulata peel extracts. Z Naturforsch C J Biosci 55: 1030 - 1034. https://doi.org/10.1515/znc-2000-11-1230

Jesionek W, Móricz ÁM, Ott PG, Kocsis B, Horváth G, Choma IM. 2015. TLC-Direct Bioautography and LC/MS as complementary methods in identification of antibacterial agents in plant tinctures from the Asteraceae family. J AOAC Int 98: 857 - 861. https://doi.org/10.5740/jaoacint.sge2-choma

Juárez Sánchez HE. 2015. Characterization of the main active compounds in leaves and flowers of the pericón plant (Tagetes lucida) by GC-MS. Doctotal thesis, National Polytechnic Institute, Mexico.

Karthikumar S, Vigneswari K, Jegatheesan K. 2007. Screening of antibacterial and antioxidant activities of leaves of Eclipta prostrata (L). Sci Res Essays 2: 101 - 104.

Kim W, Conery AL, Rajamuthiah R, Fuchs BB, Ausubel FM, Mylonakis E. 2015. Identification of an antimicrobial agent effective against methicillin-resistant Staphylococcus aureus persisters using a Fluorescence-Based Screening Strategy. PLoS One 10: e0127640. https://doi.org/10.1371/journal.pone.0127640

Klancnik A, Piskernik S, Jersek B, Mozina SS. 2010. Evaluation of diffusion and dilution methods to determine the antibacterial activity of plant extracts. J Microbiol Methods 81: 121 - 126.

https://doi.org/10.1016/j.mimet.2010.02.004

Lakshmi A, Subramanian S. 2014.Chemotherapeutic effect of tangeretin, a polymethoxylated flavone studied in 7, 12-dimethylbenz(a)anthracene induced mammary carcinoma in experimental rats. Biochimie 99: 96 - 109. https://doi.org/10.1016/j.biochi.2013.11.017

Lee H, Woo ER, Lee DG. 2015. Glochidioboside kills pathogenic bacteria by membrane perturbation. Curr Microbiol 71: 1 - 7. https://doi.org/10.1007/s00284-015-0807-9

Lehbili M, Alabdul-Magid A, Kabouche A, Voutquenne-Nazabadioko L, Abedini A, Morjani H, Sarazin T, Gangloff SC, Kabouche Z. 2017. Oleanane-type triterpene saponins from Calendula stellata. Phytochemistry 144: 33 - 42. https://doi.org/10.1016/j.phytochem.2017.08.015

Lenza VA, Morel LJF, Coppede JFernandes VC, Martinez-Rossi NM, Franca SC, Beleboni RO, Pereira PS, Fachin AL. 2009. Antimicrobial activities of ethanol extract and coumestans from Eclipta alba (L.) Hassk (Asteraceae). Lat Am J Pharm 28: 863 - 868.

Lovecka P, Lipov J, Thumova K, Macurkova A. 2017. Characterization of Biologically Active Substances from Calendula officinalis. Curr Pharm Biotechnol 18: 1167 - 1174. https://doi.org/10.2174/1389201019666180226151910

Masella R, Cantafora A, Modesti D, Cardilli A, Gennaro L, Bocca A, Coni E. 1999. Antioxidant activity of 3,4DHPEA-EA and protocatechuic acid: a comparative assessment with other olive oil biophenols. Redox Rep 4: 113 - 121. https://doi.org/10.1179/135100099101534792

Mejia-Barajas JA, Del Rio REN, Martinez-Muñoz RE, Flores-Garcia A, Martínez-Pacheco MM. 2012. Cytotoxic activity in Tagetes lucida Cav. Emir J Food Agric 24: 142 - 147.

Min-Jeong K, Krajnik MM, Kumar A, Hyun-Gyun Y. 2016. Inactivation by $405 \pm 5 \mathrm{~nm}$ light emitting diode on Escherichia coli O157:H7, Salmonella typhimurium, and Shigella sonnei under refrigerated condition might be due to the loss of membrane integrity. Food Control 59: 99 - 107.

https://doi.org/10.1016/j.foodcont.2015.05.012

Moussaoui F, Zellagui A, Segueni N, Touil A, Rhouati S. 2010. Flavonoid constituents from algerian Launaea resedifolia (O.K.) and their antimicrobial activity. Rec Nat Prod 4: 91 - 95.

Nian HM, Ching-Shu L, Chih-Han C, Jinn-Moon Y, Kai-Cheng H, Chin-Yu C, Tao-Sheng C, Shiming L, Chi-Tang $\mathrm{H}$, Min-Hsiung P. 2014. 5-Demethyltangeretin is more potent than tangeretin in inhibiting dimethylbenz(a)anthracene (DMBA)/12-O-tetradecanoylphorbol-13-acetate (TPA)-induced skin tumorigenesis. J Funct Foods 11: 528 - 537. https://doi.org/10.1016/j.jff.2014.08.009

Pagliano P, Ascione T, Boccia G, De Caro F, Esposito S. 2016. Listeria monocytogenes meningitis in the elderly: epidemiological, clinical and therapeutic findings. Infez Med 24: 105 - 111.

Regalado EL, Fernández MD, Pino JA., Mendiola J, Echemendia OA. 2011. Chemical composition and biological properties of the leaf essential oil of Tagetes lucida Cav. from Cuba. J Essent Oil Res 23: 63 - 67. 
https://doi.org/10.1080/10412905.2011.9700485

Riva A, Borghi E, Cirasola D, Colmegna S, Borgo F, Amato E, Pontello MM, Morace G. 2015. MethicillinResistant Staphylococcus aureus in raw milk: prevalence, sccmec typing, enterotoxin characterization, and antimicrobial resistance patterns. J Food Prot 78: 1142 - 1146.

https://doi.org/10.4315/0362-028x.jfp-14-531

Shahzadi I, Shah MM. 2015. Acylated flavonol glycosides from Tagetes minuta with antibacterial activity. Front Pharmacol 6: 195. https://doi.org/10.3389/fphar.2015.00195

Silva-Belmares Y, Rivas-Morales C, Viveros-Valdez E, de la Cruz-Galicia MG, Carranza-Rosales P. 2014. Antimicrobial and cytotoxic activities from Jatropha dioica roots. Pak J Biol Sci 17: 748 - 750.

https://doi.org/10.3923/pjbs.2014.748.750

Solanky D, Haydel SE. 2012. Adaptation of the neutral bacterial comet assay to assess antimicrobial-mediated DNA double-strand breaks in Escherichia coli. J Microbiol Methods 91: 257 - 261.

https://doi.org/10.1016/j.mimet.2012.08.009

Téllez-López MA, Treviño-Neávez JF, Verde-Star M, Rivas-Morales C, Oranday-Cárdenas A, Moran-Martínez J, Serrano-Gallardo LB, Morales-Rubio M. 2013. Evaluation of the effect of methanol extract of Tagetes lucida on testicular function and sperm quality in male Wistar rats. Rev Mex Cienc Farm 44: 43 - 52.

Tereshuk ML, Riera MVQ, Castro GR, Abdala LR. 1997. Antimicrobial activity of flavonoids from leaves of Tagetes minuta. J Ethnopharmacol 56: 227 - 232. https://doi.org/10.1016/s0378-8741(97)00038-x

Vega-Menchaca MC. 2013. Identificación parcial de principios activos de diez plantas medicinales del norte de México con actividad biológica contra bacterias patógenas de aislados clínicos y cepas de referencia. Doctoral thesis, Autonomus University of Nuevo León, México.

Wagner H, Bladt S. 2001. Plant drug analysis a thin layer chromatography atlas. Ed. Springer, New York, USA.

Ye XJ, Ng TB, Wu ZJ, Xie LH, Fang EF, Wong JH, Pan WL, Wing SS, Zhang YB. 2011. Protein from red cabbage (Brassica oleracea) seeds with antifungal, antibacterial, and anticancer activities. J Agric Food Chem 59: 10232 - 10238. https://doi.org/10.1021/jf201874j

Zater H, Huet J, Fontaine V, Benayache S, Stévigny C, Duez P, Benayache F. 2016. Chemical constituents, cytotoxic, antifungal and antimicrobial properties of Centaurea diluta Ait. subsp. algeriensis (Coss. \& Dur.) Maire. Asian Pac J Trop Med 9: 554 - 561. https://doi.org/10.1016/j.apjtm.2016.04.016 